\title{
Acknowledging Trade-offs and Understanding Complexity: Exurbanization Issues in Macon County, North Carolina
}

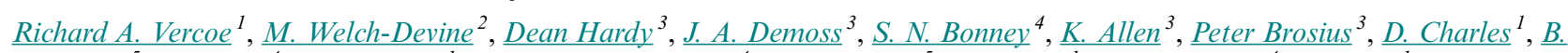

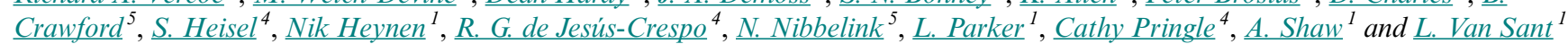

\begin{abstract}
We applied an integrative framework to illuminate and discuss the complexities of exurbanization in Macon County, North Carolina. The case of Macon County, North Carolina, highlights the complexity involved in addressing issues of exurbanization in the Southern Appalachian region. Exurbanization, the process by which urban residents move into rural areas in search of unique natural amenities and idealized lifestyles, can often have a dramatic impact on the local economy, culture, and environment. Within Macon County, complex debates and tensions among multiple stakeholders struggle to address local residential development. How can better problem definition benefit rural communities in addressing exurbanization pressures and effects? We asserted that a key factor in the shortcomings of previous solutions was the shortsightedness inherent in policy that attempts to treat individual symptoms without being able to adequately characterize the underlying problem. The goal of the integrative framework is to initiate an iterative process of transparent negotiation, which recognizes a range of potential choices to be considered and to embrace the social complexities that can at times overwhelm scholars and practitioners, inviting simplification and polarization of the issues. This new and emerging framework offers a novel way of approaching conservation and development issues where other frameworks have failed. It helps acknowledge the difficult choices, i.e., trade-offs, that have to be made in a material process like exurbanization. Trade-offs will be necessary in any negotiation related to conservation. Therefore, conflict surrounding specific values, e.g., cultural, financial, or ecological, must be acknowledged upfront to move deeper into issues of plurality. Given the complexity, understanding how the process of exurbanization is being played out within Macon County provided not only an opportunity to demonstrate the functionality of an integrative approach, but also a call for further study of exurbanization dynamics.
\end{abstract}

Key Words: conservation; development; ecological; exurbanization; integrative conservation; trade-offs

\section{INTRODUCTION}

There are increasing calls in conservation for an approach that explicitly defines and acknowledges the various trade-offs involved in decision making (McShane et al. 2011). Identification of trade-offs, recognition of dissonant and conflicting views, and an understanding of the different ways in which trade-offs are understood and framed, ideally allows for deliberate negotiation among the myriad stakeholders of conservation projects (Hirsch et al. 2010, McShane et al. 2011). Conservation and development discourse must move beyond the simplified 'win-win' rhetorics that have underscored conservation efforts for the past 20 years, through such initiatives as integrated conservation and development programs (ICDPs), community based conservation (CBC), and now market-based mechanisms (MBM; Brandon and Wells 1992, Western and Wright 1994, Costanza et al. 1997, Daily 1997, Phillips 2003). Win-win approaches in conservation and development often ignore interdependent and interconnected complexities (McShane and Wells 2004, McShane et al. 2011) thus limiting the scope of possible solutions and affecting the longterm sustainability of outcomes. The challenges and pitfalls of past win-win approaches have led to the realization that although some peoples, species, or habitats may benefit from particular conservation and development interventions, others will not; there are always winners and losers. Identifying trade-offs requires recognition of the complexities of both social and ecological systems and their linkages and interactions (Cash et al. 2006, Liu et al. 2007). The integrative framework addresses trade-offs by allowing for the consideration of multiple perspectives and ways of thinking about these complex social-ecological problems (Hirsch et al. 2013).

We drew on the work of the Advancing Conservation in a Social Context initiative (ACSC 2011) to address exurban development in Macon County, North Carolina. We apply ACSC's integrative framework, which calls for an iterative and deliberative process that values the input of multiple actors and perspectives, to understand the social and biophysical issues specific to this area.

The integrative framework operates on the assumption that good decisions are more likely to come from plurality in problem definition and a robust characterization of problems, facilitating the recognition and negotiation of trade-offs (Hirsch et al. 2013). We demonstrate how the integrative framework guided us to ask new questions regarding exurbanization in Macon County. We describe exurbanization in a broader context through a review of the scholarly literature that illustrates the drivers and potential consequences of exurbanization in various regions of the world. We place exurbanization in the context of a specific site, Macon County, North Carolina. Finally, we show how the application of the integrative framework leads to more holistic ways of defining and approaching conservation challenges, which ideally will affect decision making processes.

\section{Social-ecological consequences of exurbanization}

Exurbanization describes a global phenomenon that has been gathering momentum throughout the last half century.

${ }^{1}$ Department of Geography, University of Georgia, ${ }^{2}$ Center for Integrative Conservation Research, University of Georgia, ${ }^{3}$ Department of Anthropology, University of Georgia, ${ }^{4}$ Odum School of Ecology, University of Georgia, ${ }^{5}$ Warnell School of Forestry and Natural Resources, University of Georgia 
Spectorsky (1955) first used the term to discuss the new class of people who were moving beyond the suburban fringe of New York City in search of a rural lifestyle with urban accessibility. This process has been continually facilitated by improved transportation, increased flexibility of work schedules, and the rise of virtual commuting, all of which have allowed people to maintain urban incomes while increasing their living space (Nelson and Dueker 1990). Definitions of exurbanization vary, but there are several commonalities throughout. Most definitions emphasize the characteristics of exurban migrants: people who possess an unequal access to external capital and the desire to maintain the facilities of urban living within an idealized rural atmosphere (Berube et al. 2006). Exurbanization provokes a boom in housing growth in rural areas, which sometimes creates tension between long-term rural residents and new migrants (Gosnell and Abrams 2011). Perhaps ironically, if exurbs continue to grow and transition into suburbs, exurban migrants instigate a process of development that may undermine the initial motives for relocation. Gragson and Bolstad (2006) refer to it as a phenomenon in which urban residents who are attracted to rural amenities such as scenic resources, low cost of living, and the absence of zoning restrictions, build recreational properties on rural lands, thus transforming the rural nature of these lands through their cumulative building activities. Broader definitions include seasonal second-homes under the term exurbanization, which suggests that the characterizing element is the distance between the place of residence and the source of income (Esparza 2009). A parallel body of literature examines the same pattern of urban to rural migration through a different lens, that of amenity migration, emphasizing that migrants tend to be drawn disproportionately to particular natural amenities (McGranahan 1999). Exurbanization and amenity migration are closely related to a third term, residential tourism, which describes the seasonal migration of retired individuals to areas with numerous natural amenities (Casado-Diaz 1999). We employ the term exurbanization as a more holistic definition that focuses not only on the drivers of migration patterns but also on the resulting impacts to the landscape.

Over the past century, migration from urban to exurban mountain regions in the United States has been driven by social and technological trends. Initially, exurban population growth was thought to be linked to technological advances that allowed employees to live and work further from urban centers (Nelson and Dueker 1990, Dent 1998); however, current causal evidence is still equivocal (Culbertson et al. 2008). Still, there has been a noticeable increase in job opportunities away from urban areas, defined by Nelson et al. (1995) as "exurban industrialization." Broader social trends provide a better foundation for explaining population growth in these areas. Increases in retirement and resort communities, coinciding with the retirement of the baby boomer generation in recent decades account for population growth away from cities in the United States (Glennon and Kretser 2005, Culbertson et al. 2008). Additionally, the population of wealthy second-home or seasonal residents has grown in exurban communities. Second homeowners in the Southern Appalachian Mountains are attracted to these regions for aesthetic benefits and natural amenities of the land including: high elevations, temperate climate, access to streams and open spaces, and recreational opportunities (SAMAB 1996, Cho et al.
2005, Culbertson et al. 2008). Overcrowding and rising real-estate prices in traditional destinations, such as Nantucket and Rhode Island, have also motivated many retirees and second homeowners to explore alternative regions, such as the Southern Appalachians, where they can obtain property at lower cost (National Association of Realtors 2002). The rapid growth rates to which these factors contribute lead to economic and social shifts that can have profound impacts on resident populations.

Many formerly rural communities that once specialized in resource extractive industries, like mining and timber, are now shifting to service industries such as tourism (Esparza 2009). In some areas, especially in the developing world, exurbanization may result in increased employment opportunities, improved security and safety, new road construction, and increased market access (Wittemyer et al. 2008). However, in most areas, although residential development and tourism do provide jobs for local populations, they do not assure steady economic development, especially in times of crisis (Robbins et al. 2012). Furthermore, demographic and economic shifts can increase the cost of living by increasing land and housing prices (Costello 2007, McCarthy 2008), increasing stress on utilities, and necessitating new, and complex development ordinances (Esparza and Carruthers 2000). The shifting terrain of livelihood issues such as ambiguous property rights, informal resource use and access, and the representation and acknowledgment of local histories in these intense periods of demographic change can be seen in the tensions that manifest between long-time residents and migrants (Boucquey et al. 2012).

These costs and benefits in exurban transformation include not only economic, but also cultural dimensions that Esparza and Carruthers (2000:24) characterize as the "commodification of place." Though an influx of people and capital has the potential to generate renewal (Rasker 2006), as a community becomes a commodity, local histories and meanings can take a back seat in resource-use decision making, and legitimate local users can be disenfranchised (Boucquey et al. 2012). Wealthier new residents may arrive with new expectations about social-ecological and resource concerns that can be incongruent with traditional rural values. For example, locals may perceive forests through a utility value, whereas newcomers prize aesthetics (Egan and Luloff 2000). As a result conflicts often emerge around ideas about whether longtime residents should have to adapt to the newer interest(s) of outsiders, or migrants should adapt to the lifestyles of long-time residents (Egan and Luloff 2000).

Exurbanization produces notable environmental impacts as well. Proximity to natural amenities, such as forest reserves, is believed to be one of the main drivers of exurban development (McGranahan 1999, Culbertson et al. 2008, Kirk et al. 2012). However, though greater access to nature increases the economic value of exurban properties, the process of exurbanization itself tends to degrade the quality of the surrounding natural resources, which ultimately decreases the conservation value of these lands (Cho et al. 2005, Radeloff et al. 2010, Kirk et al. 2012). Development in Macon County has recently been following the general trend of moving away from main roads and toward forested areas where residents have better access to these natural assets, resulting in a steady decrease in forest area since 1990 and a $361 \%$ increase in private roads between 1954 and 2009 (Kirk et al. 2012). 
Studies of the ecological impacts of exurbanization have demonstrated its effect on forest fragmentation and watershed integrity. In Macon County, forest fragmentation often occurs in the context of exurbanization because of the preference for building in forested areas and/or near national forest land (Turner et al. 2003). This can interfere with the dispersal and migration of local native wildlife (Glennon and Kretser 2005), concomitantly decreasing their ability to reproduce as the amount of suitable habitat decreases (Reynolds-Hogland and Mitchell 2007). Generally, as forest edge increases the acreage that is considered to be forest interior decreases. This is a process that favors the competitive ability of introduced generalist species, which are often invasive, over those that are native, hindering their ability to persist (Glennon and Krestor 2005, Kuhman et al. 2010). The end product of this process is a potential homogenization of the landscape as it experiences the local extinction of many of its native flora and fauna (Turner et al. 2003, Glennon and Kretser 2005). Fragmentation can reduce the amount of communal land available for hunting and create tensions regarding accessibility (Storm et al. 2007). The exurbanite preference to settle in previously undeveloped regions also increases the likelihood that wildlife will be exposed to domestic pets, roads and traffic, and human activity, which all result in increased human-wildlife conflict and wildlife mortality (Glennon and Kretser 2005).

Exurban regions often lie outside the coverage area under formal zoning ordinances, making it easier for development to take place along river floodplains and riparian zones (Canfield and Hawkins 2009). Riparian deforestation can result in increased stream temperatures (Clinton and Vose 2006, Price and Leigh 2006, Audrey and Hawkins 2009), increased sedimentation (Clinton and Vose 2006, Price and Leigh 2006), and the introduction of exotic species (Audrey and Hawkins 2009). These processes, in turn, result in the degradation of stream habitats for macroinvertebrates and fishes (Brett 1956, Swift and Messer 1971, Walters et al. 2009). Other potential impacts of anthropogenically altered stream habitats include the possibility of increased disease transmission with spread into novel environments and hosts (Bradley and Altizer 2007) and the general displacement of native species (Lehtinen et al. 1999, Maestas et al. 2001, Hansen et al. 2005, Kuhman et al. 2010). In the Little Tennessee Watershed (LTW) where Macon County lies, ecological consequences are a particular cause for concern because of its status as a biodiversity hotspot (Harrison 2005). The region is home to endemic species such as the southern brook trout (Salvelinus fontinalis) and also rare species like the hellbender (Cryptobranchus alleganiensis), America's largest salamander (LTWA 2007).

The impacts of exurban development not only result in changes to wildlife habitat, but also can pose significant hydrological problems for human populations and aquatic species. Although exurban development leads to fewer hydrological changes than development at urban densities, the decrease in forested land and increase in impervious surfaces, e.g., roads and houses, in rural areas cause increases in surface runoff and erosion (Wenger et al. 2011). This is especially true because exurban areas tend to have fewer resources for stormwater and road infrastructure to mitigate these impacts (Canfield and Hawkins 2009). This poses a significant risk to the Southern Appalachian region, which has been referred to as the "water tower" of the Southeastern U.S. (Webster et al. 2012). In addition, exurban houses are often distant from sewer infrastructure, and thus are mostly serviced by septic systems that are more difficult to maintain and regulate. Poorly managed septic systems may lead to fecal coliform pollution (Clinton and Vose 2006, Price and Leigh 2006, Lohse and Merenlender 2009), which is a significant potential human health hazard (NCEEP 2010). Septic system mismanagement has also been associated with increases in nitrogen loading in rivers (Kaushal et al. 2006), which may increase the likelihood of algal blooms, decrease dissolved oxygen content (NCEEP 2010), and disrupt the stream food web. These effects may lead to changes in macroinvertebrate and fish populations (Cross et al. 2007, NCEEP 2011). Overall, sedimentation, organic pollution, and nutrient loading impair habitat for aquatic species and decrease the aesthetic and recreational value of the watershed (LTWA 2007). Within the study area, Webster and colleagues (2012) reported a trend of greater nitrate concentration in relation to mountainside development within 58 streams throughout the watershed. As Macon County's development pattern moves toward suburbanization (Kirk et al. 2012), it becomes clear that it will be increasingly important to consider both the changes in the local hydrology that are a result of increased imperviousness, as well as the infrastructure and regulatory responses that could address these issues.

\section{Exurbanization in the context of Macon County}

Land use histories, economic trajectories, and demographic changes in Macon County are critical to understanding current debates around exurbanization (Kirk et al. 2012). Among longtime residents in areas like Macon County, there is a strong tradition of individual and family independence that is typified in the resistance to land-use restrictions (Gragson and Bolstad 2006). This has been a factor in the slow pace of the development of land-use regulations in the region. The increase in total number of residences, and location of these residences, has dramatically affected the local economy, culture, and environment. Although development has brought construction and service industry employment to the region, there are growing concerns about the relationships between exurban growth and the increased probability of landslides on steep slopes and deteriorated aesthetic and cultural values of the mountains. With the economic downturn many local residents have been financially affected; yet, simultaneously some may be relieved to see an end to the building boom because of the concerns over increasing environmental and social impacts. Although Macon County faces unemployment issues, citizens are faced with hard choices involved in either allowing unregulated development to continue or exploring other economic alternatives and visions for the area as expressed by various stakeholders in the region.

The processes associated with exurbanization are forcing stakeholders in areas like Macon County to face hard decisions and to succinctly analyze both the social as well as the ecological impacts of development in their regions. Within Macon County, any desire to reconcile the area's ongoing development with the preservation of natural resources that have traditionally attracted exurbanites will require a willingness to consider the problem from multiple perspectives. In the next section, we introduce the Advancing Conservation in a Social Context's (ACSC) Integrative Framework as a way of approaching the issue of exurbanization within Macon County through an iterative process designed to facilitate multi-perspective discussions that 
ultimately seeks out "better problem definitions that open the way to generating and communicating better decisions" (Hirsch et al. 2013).

\section{THE INTEGRATIVE FRAMEWORK}

The integrative framework (Fig. 1) is a conceptual architecture that 'makes space' for multiple perspectives and ways of thinking about complex problems and trade-offs (Hirsch et al. 2013). It was created by an international team of academics and practitioners assembled by the John D. and Catherine T. MacArthur Foundation's Conservation and Sustainable Development Program as part of a four-year initiative called Advancing Conservation in a Social Context (2007-2010). In response to the Foundation's frustration with a long series of unrealistic win-win funding proposals, this collaborative effort produced a new framework for examining conservation problems. The integrative framework highlights the critical need for: (1) the explicit acknowledgment of trade-offs during the problem formulation phase; (2) the recognition that there are many different ways of perceiving these trade-offs; and (3) a more nuanced analysis of these trade-offs in decision-making processes.

Fig. 1. The Advancing Conservation in a Social Context (ACSC) Integrative Framework. Source Hirsch et al. 2013.

\section{The ACSC Integrative Framework}

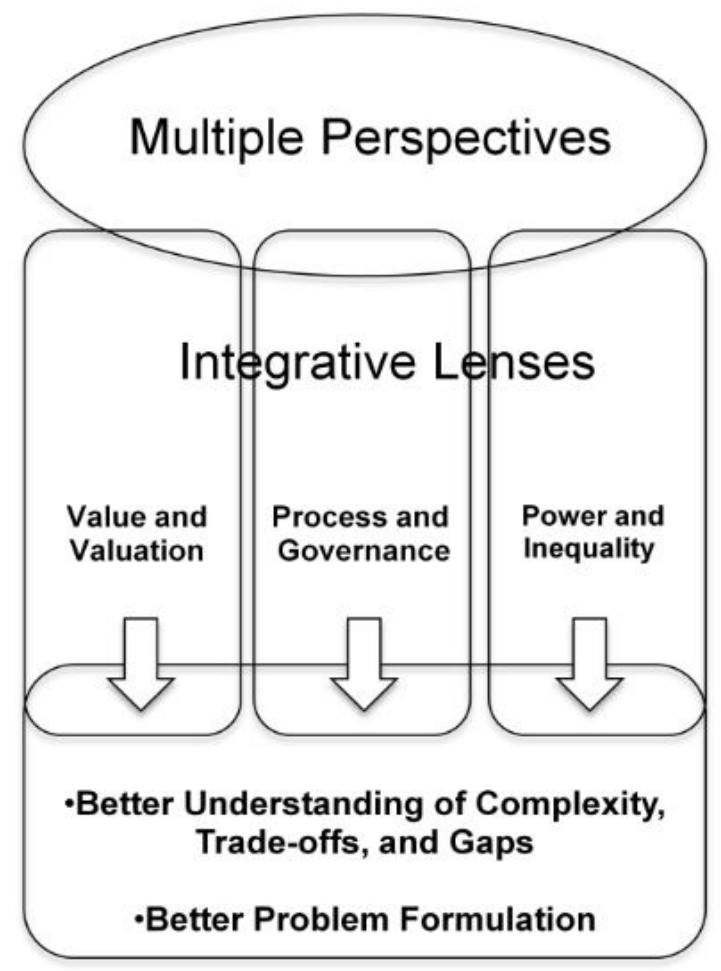

The integrative framework is intended to help guide a collaborative process that includes reflection, research, and action. By articulating multiple perspectives through the integrative lenses, it is possible to explore different assumptions, concepts, and ways of thinking. Ideally, the multiperspective process allows for parallel perspectives to be equally expressed in the search for understanding and addressing trade-offs and complexity. This process is intended to result in better problem definitions, improved communication, and the formulation of better research approaches.

Given the complexity of development issues in Macon County, it is necessary to adopt an approach that takes into account multiple stakeholders' perspectives, which are always partial and potentially conflicting. The goal of the integrative framework is not to produce a singular solution, but rather to initiate an iterative process of transparent negotiation that recognizes a range of potential choices to be considered and that each has its own unique outcomes (McShane et al. 2011). It is also designed to clarify and embrace the social complexities that can at times overwhelm scholars and practitioners. Further, it is grounded in the recognition that people's "perspectives are embedded in social systems and preexisting power relations" (Hirsch et al. 2010:259). Included in this understanding is the explicit acknowledgement that not all actors are equally empowered to shape the overall nature of the debate and that actors may at times consider some values to be non-negotiable. Given these considerations, the integrative framework attempts to frame trade-offs in a manner that transcends traditional cost-benefit analyses.

McShane et al. (2011) assert that trade-offs are integral to conservation management projects, and that diverse socialecological values are not likely to mesh neatly together into winwin solutions for every stakeholder. They argue that cycles of optimism and disillusionment, in which conservation problems and universal solutions are cast into a positive light by and for policy makers and the public, followed by management and development failures, are common when complexity is ignored or simplified (McShane et al. 2011). Ultimately, the integrative framework is a tool to help communities tackle conservation dilemmas through a process, which facilitates their understanding that the issues are complex and that tough choices must be made, but that the opportunity does exist for "genuine reflection, honest communication, and responsible action" (Hirsch et al. 2010:263).

The lenses of the integrative framework are meant to highlight the multiple ways in which complex problems can be addressed. These lenses allow for simultaneous engagement with complex conservation issues that are too often siloed. The three lenses are values and valuation, process and governance, and power and inequality. Though other lenses could be elaborated, these are the lenses put forth in the original ACSC integrative framework document and the ones that have been field tested and have proven promising at encompassing a large range of approaches for studying nature and society (Zia et al. 2011, Anderson et al. 2012, Ráez-Luna and Dammert Bello 2012). Each of these lenses has its own starting assumptions from which a set of questions and core concepts flow (Table 1).

For the value and valuation lens, the underlying assumption is that good decisions come from good methods for accounting for multiple values and comparing them. Through the use of measurements, indicators, and analyses of commensurability, this lens aims to identify what is important for various actors, how it can be counted, and the issues that arise from trying to compare 
values across different conceptual and cultural contexts. The process and governance lens rests on the assumption that good decisions come from good public processes. Its core concepts, inclusion, voice, and authentic engagement, provide a language for asking questions about who should be involved in decision making and through what mechanisms. Finally, the power and inequality lens starts from the assumption that nothing is natural or neutral, including valuation and governance, but that all are shaped by the exercise of power. Discourse, agency, and hegemony are the key concepts that allow one to uncover the forms of power that shape knowledge claims and policy framing (Hirsch et al. 2013).

Reading a complex issue through these lenses is not an exercise in synthesis; rather, there are moments of disjuncture and incommensurability that must be appreciated and acknowledged. The integrative framework is not a master model. Instead, by reading the problem through these multiple lenses and highlighting the moments of convergence and divergence, it can be better defined and engaged.

Rather than seeking an optimal solution in Macon County that satisfies every stakeholder, we used the lenses of the integrative framework to identify stakeholder's multiple views and values and to acknowledge the necessity of trade-offs and hard choices as citizens negotiate development ordinances, especially regarding steep-slope building regulations (McShane et al. 2011).

\section{Value and valuation lens}

The value and valuation Lens of the integrative framework shows the difficulties inherent in any process that translates complex values into monistic values, or exchange values, for the purpose of facilitating comparison (Hirsch et al. 2013). The literature on exurbanization suggests that conservation agendas are often set up in direct opposition to those of economic development. As an example, the debate over housing development in Macon County is often framed as one of competing values. This binary framing can be unproductive, as cases of conflict are often more complex than this and involve multiple actors with diverse agendas. The binary framing also assumes that these values can be easily defined, measured, and compared. Analysis using the value and valuation lens, however, shows that the assumptions of the binary framing are incomplete.

In their initial encounters, stakeholders from diverse constituencies may believe they share similar values that, if fulfilled, will result in win-win outcomes. For example, real estate developers, second-home buyers, and long-time residents of Macon County might all agree that safety is a collective concern. However, recent controversies surrounding the production of a set of hazard maps designed to consider 'safety' as a value suggest that such a seemingly universal objective can be conceptualized and ultimately prioritized very differently among stakeholders. Similarly, although land stewards may use the conservation risk of developing an area as an argument for preservation, developers may view the conservation risk as acceptable in light of economic gains, instead focusing more on the economic risk of slowed growth. Key questions include: what does safety in relation to these forms of risk mean in this context, and how is safety measured?

The example of fecal coliform pollution illustrates these concerns. The hazard maps that were produced show slope steepness and stability; however, though fecal coliform pollution presents a potential health hazard for humans, this indicator of safety is not identified on these maps. Why is it that steep slope is defined as a hazard when fecal coliform is not represented? Part of the explanation for this discrepancy lies in the fact that these safety indices do not have a singular and mutually agreed upon valuation or priority when viewed by different stakeholders. Any analysis must pay attention to who defines and measures safety as well as what indicators they use for valuing it. Rather than conceptualizing safety as a value that automatically promotes a win-win scenario, it is more productive to explicitly consider potential trade-offs and incommensurabilities in values that are important for decision making.

Analyzing a value through a critical lens helps us explore the different conceptual frameworks that stakeholders are drawing upon and how this may lead them to prioritize certain values over others. The indicators chosen to represent specific values, therefore, depend not on the value per se, but on one's interpretation of that value. Even if tangible indicators of values exist and can be measured, it is important to acknowledge that multiple forms of values may be incommensurable. For example, the local land trust might see themselves as stewards of the land and focus on ecological preservation as a long-term goal. Developers might see the need for continued economic growth as imperative to the immediate needs of the community. These perspectives are both temporally incommensurable, i.e., longterm vs. short-term, as well as potentially incompatible at a policy level. Each value set produces different outcomes, each outcome has different relationships to underlying values, and each stakeholder has different perceptions of these values. For example, a decision to develop steep slopes will likely increase river sedimentation and fecal coliform pollution (Clinton and Vose 2006, Price and Leigh 2006). These environmental effects present a health hazard to the community that may be acceptable to certain stakeholders, relative to the economic gains associated with construction. However, increased sedimentation causes a secondary effect of degradation to trout habitat, which may reduce economic gains associated with recreational opportunities over the long-term. Given this context of trade-offs, it is highly unlikely that certain values can be accurately quantified in a single metric and compared across stakeholder groups to show the overall cost or benefit of a decision.

The integrative framework provided by the ACSC project (ACSC 2011) functions on the premise that the real power of discussing trade-offs is not necessarily in calculating costs and benefits, but in encouraging a diverse group of stakeholders to consider the multiplicity of viewpoints. Identifying hard choices up front and acknowledging that certain values are difficult to quantify and compare are important first steps in addressing long-standing disputes (Hirsch et al. 2010).

\section{Process and governance lens}

The process and governance lens adds to the integrative framework a better awareness of how institutional contexts shape values and how particular metrics are ultimately prioritized as the operational norm. By examining the procedures through which decisions are ultimately made, it becomes possible to identify the ways the role of governance potentially hinders or facilitates a more inclusive decision-making process. In the case of Macon County, we used the process and governance lens to critically 
Table 1. Integrative Framework (IF) as applied to Macon County, North Carolina, USA. This table illustrates a sampling of the questions that arise from use of the integrative framework and some brief examples of the information that these questions elicit. This table is not meant to be an exhaustive chronicling of the questions raised by the IF or of the data produced. Rather, it is meant to illustrate how looking through different lenses highlights and obscures different areas of the problem and how when the lenses are taken together we arrive at a more holistic understanding of the issue or problem.

\begin{tabular}{ll}
\hline \hline Lens & The Conservation Context of Macon County \\
\hline Values and valuation & What is important or valuable in this region and who values these things? \\
& Water quality - state water specialists (e.g., North Carolina Department of Natural Resources workers), town water \\
& managers, conservation activists, residents. \\
& Healthy fish populations - anglers, conservationists. \\
& Thriving economy/livelihoods - residents, government officials, developers. \\
& Private land rights, freedom to develop without regulations - some residents, developers. \\
& Aesthetic value of mountains - many new residents, some longer term residents. \\
& Safety - residents, emergency responders, government officials. \\
& How can these values be measured and compared? When might it be difficult to compare? Are there some values that \\
& cannot be measured or compared? \\
& Development vs. support of agriculture vs. environmental protection. \\
& Priorities of long-term vs. newer residents. \\
& Different indices of safety and risk and their relative importance (fire, landslide, accessibility).
\end{tabular}

Process and What processes for change currently exist and what are the possibilities for new processes?

governance

Education, regulation, voluntary self-regulation.

Whose voices are included?

Developers, bankers, conservationists, local residents - not in equal measure.

How do existing institutions and governance structures shape the identification and negotiation of problems?

Political manipulation by certain actors, reconstitution of the planning committee, overall lack of transparency.

General resistance to governmental control, regulation, taxes, zoning, etc.

Power and inequality Who is defining the issue or problem?

Small, vocal minority.

What forms of power influence the debate?

Financial, cultural, political, knowledge (access to information).

Those with money invested in steep slope lands have had a larger voice.

Who wins and who loses?

Environmentalists, in particular, seem to lack any real power.

Is the issue simplified in ways that leave out voices and priorities?

Framed as development vs. environment and developers vs. conservationists. Serious discussion about safety not included, developers who favor an ordinance restricting development are silenced.

explore access to decision-making processes and government's role in addressing development and exurbanization.

A contentious political debate has developed in Macon County around the issue of development and the creation of a steep-slope ordinance for the region. Although drafted, no comprehensive steep-slope ordinance has been enacted for the region. A subcommittee of seven individuals appointed by the Macon County Planning Board (MCPB) began developing this ordinance in June 2009 and provided recommendations to the board in February 2010. After more than a year of revisions and months of debate, the MCPB eventually tabled the draft ordinance in August 2011. In its place, a construction ordinance was passed. Members of the planning board saw this construction ordinance as establishing a common ground among those involved in the steep-slope debate. The construction ordinance has more lenient standards, and building codes are not tied to the landslide hazard maps, nor are they dependent upon slope steepness or stability. With the tabling of the steep-slope ordinance and replacement by a less explicit construction ordinance, a comprehensive ordinance that addresses concerns for all stakeholders has never been enacted for the region despite seemingly popular public support for the measure.

Development governance in Macon County is a mosaic of specialized departments and commissions, each holding one piece of the picture, but none able to provide comprehensive governance with independent establishment of regulations for development in the region. There are a handful of state and local government divisions, in addition to the MCPB, that create or enforce ordinances, codes, and other legally binding policies pertaining to steep-slope development. The county Department of Planning, Permitting and Development (DPPD) is responsible for enforcing building codes as well as erosion, sedimentation, and flood ordinances. The DPPD enforces existing policies, rather than developing new ones. The North Carolina Department of Environment and Natural Resources creates development ordinances to protect water quality and wildlife habitat.

Monthly MCPB meetings are open to the public, with public comment periods for proposed ordinances. In 2008, a series of charrettes, open to the public, were held by the Community Foundation of Western North Carolina (Mountain Landscapes 
Initiative) to envision the future of development in Western North Carolina (WNC). The outcome of these charrettes was a toolbox of best management practices for development and planning in the WNC mountains. Organized citizen groups can shape the process of steep-slope development by influencing decision making, financing campaigns, educating the public, and molding the discourse about the debate.

Inclusion of multiple voices in the processes of governance is essential to ensure that outcomes are publicly supported and are in the best interests of multiple stakeholders. The process and governance lens allowed us to focus on the effectiveness of the government processes and procedures related to development in Macon County. Although the MCPB meetings and the Community Foundation charrette were open to the public, it is unclear if attempts to involve residents in development discourse were effective. To better determine inclusive processes, it is important to identify who was able to participate and who was left out, and what the reasons were for their inclusion or exclusion. Is there evidence that individuals or groups possess, or are perceived to possess, power that has unequal influence over political outcomes? Without this kind of analysis and the inclusion of multiple voices, governance will be undermined and processes will not reflect differentiated and mixed opinions of the residents of Macon County.

Governance processes have the opportunity to be participatory and consensus oriented in nature, and elected officials are often accountable, transparent, responsive, and effective as a result of their mandate(s). Working under this assumption, it follows that within the context of development in Macon County, appropriate governance should be to find solutions to support and serve a community's long-range economic development strategies. How then have governing institutions responded to different arguments and constituencies that have formed in response to development in Macon County, and have these institutions fulfilled their obligations in the context of appropriate governance? We draw attention to the following factors and questions that reflect the considerations of the process and governance lens: (1) the multiple processes of engagement: how has prior input via public processes, such as community meetings and charrettes, been synthesized and merged into governance decision making? (2) To what degree has key scientific data and input by targeted agencies, i.e., U.S. Forest Service, U.S. Geological Survey, Land Trust of the Little Tennessee, University of Georgia, etc., helped guide and determine management directives and processes in steep-slope development? (3) Do certain scientific, social, cultural, or other inputs maintain a privileged place in defining Macon County governance, and who creates or has access to those inputs? (4) Given the existing imbalance of voice and power, i.e., political influence of an active minority base, how can community networks and area partnerships at multiple scales and across diverse constituencies continue to expand their voice in governance, share ideas and solutions, and demand public access and disclosure of all relevant information for making informed decisions about steep-slope development? The current governing institutions have the capacity to regulate steep-slope development; the question becomes one of political will to adopt regulations that reflect multiple values. However, different stakeholders can encourage and benefit from more transparent governance in specific ways. By capitalizing on the existing institutions and structures in place, Macon County residents can foster increased consensus and recognize trade-offs around basic steep-slope regulation. Affected communities or stakeholders have the opportunity to understand their rights and obligations, advocate for accountability and transparency in elected officials, and identify solutions and iterative planning processes that support their community's long-term vision and goals.

\section{Power and inequality lens}

When exurbanization in Macon County is analyzed through the power and inequality lens, multiple domains emerge that structure the way the issue is articulated and negotiated among the diverse group of stakeholders. These domains, among others, are at least cultural, political, financial, and epistemological, and include both implicit and explicit forms of power. They frame the discourse emerging from interactions among stakeholders and partially define the process of trade-offs. How trade-offs are negotiated is affected by how forms of inequality manifest in various ways including: (1) differential access to information about risk, e.g., landslide hazards; (2) unequal access to political processes, e.g., policy making; (3) differential access to knowledge and to the claims of knowledge creation, e.g., sustainable development practices; and (4) inequality of wealth. If these power dynamics and inequalities are acknowledged, the problem can be redefined as one of articulating a pluralism of values and partial perspectives to negotiate trade-offs. We outlined how power and inequality can determine whose voices are most important in shaping exurbanization in Macon County.

An historical perspective of a region affords the opportunity to examine the cultural context in which the multiple forms of power and inequality have emerged and interacted. Without this historical background, any analysis loses sight of long-term trajectories and the associated intentions of decision makers and other actors. In the case of Macon County, recognizing the economic history of mining and agriculture that shifted into the current economy based on tourism, which is facilitated by amenity migration and exurbanization, may illuminate how some of the contentions over development regulations are being articulated and negotiated. Specifically, disagreements concerning future land-use and the ordinances that regulate development may arise from a socially heterogeneous group of citizens including multigenerational and newly immigrated families, e.g., retirees from Florida, with divergent life histories and ideas about development. Moreover, disparities in access to the financial gains resulting from the 'new economy,' which depends upon the tourist service industry and new home building, may create new tensions within groups of long-term residents.

Many questions result from the link between historical processes and a nuanced appreciation of power and inequality dynamics in Macon County. Which stakeholders have the power to create and endorse knowledge bases? Are certain types of knowledge privileged and how has that privileging shifted through time and in response to exurbanization? For example, is scientific data of exurban disturbance privileged over concerns for the market value of property development? Are exurbanite values, varied though they may be, given more weight in governance than the values of stakeholder groups that claim a connection to the landscape through descendants? What forms of power do developers, residents, government officials, and scientists, among other stakeholders, display when debating steep-slope development? Who has the power to determine the trajectories of economic, 
ecological, and cultural development in the region? The strength of analysis through the power and equality lens lies in making forms of influence explicit so that analysis of historic and structural inequalities and management of trade-offs are wellinformed and articulated (Hirsch et al. 2013).

Economic power often influences who is able to bring their voices successfully to the table in negotiations and who has the most incentive. Because the outcome of steep-slope regulation debates will affect financial futures, money serves as a motivating force behind their voices. In addition, those that have access to more capital may be more willing to hire attorneys or may have the time to represent their voice at public hearings. Thus, the amount of capital invested and the amount of capital at one's disposal are factors contributing to inequality and dynamics of power in this debate.

Though many find it easy to blame developers and lending agencies for disparities in wealth and access, and even for some of the consequences of failing steep-slope development projects, realizing that these groups may be operating with limited information about developing in steep slope areas should allow for more productive negotiations and realistic agreements among groups. Developers have unequal access to information about steep-slope hazards, and they lack the power to create and enforce development regulations. Critiques of financial inequality are not about blaming developers, but are instead about recognizing that under the current state of incomplete information and lack of regulation consensus, developers have few incentives to change their practices.

In terms of equal access to information, the removal of landslide hazard information from the Macon County website is another case in point. As debates around development regulation raged, state of North Carolina officials developed landslide hazard maps that were temporarily posted on the Macon County website. Shortly after opponents of regulation questioned the utility and authority of the maps they were removed from the local government website. In this situation the needs of opponents were perceived to have outweighed the benefits of retaining hazard information on the county website. It is possible that the desire to maintain current land values was privileged, although the identity of the person who authorized the removal of the maps is unknown.

In this discussion of power and inequality, we must acknowledge that power does not necessarily reside in explicit displays of wealth. For example, less explicit power resides in the abilities of stakeholders to engage with development issues through, for example, their rights as private landowners. Landowners have sometimes denied access to scientists conducting studies on the ecological effects of steep-slope development. Access to power is nuanced and contextual, and there are numerous other ways that stakeholders can express their agency regardless of access to monetary capital.

There is an inherent risk when approaching conservation issues using a pluralistic methodology. Though all stakeholders possess some form of power, some stakeholders will have more influence over political and economic processes. The most explicit form of power addressed here regarding development in Macon County is the political power to confirm or veto regulations and zoning pertaining to development ordinances. However, less explicit political power can sit with those who are able to influence political decisions. It is unclear in this debate which parties or individuals outside of official political office have the capability to influence political decisions in Macon County, but the current elected body has explicit power to mandate or avoid passing regulations. With the explicit power of making final determinations on regulations around development in the region, the political offices in which this power sits are of extreme importance to the many stakeholders who are deeply invested in the region; thus, a deeper analysis of how power and inequality influence the political domain are of crucial importance. In this setting, new issues of power and inequality will emerge, and an iterative process of analysis will be necessary to effectively represent all stakeholders affected by Macon County development.

\section{CONCLUSION}

Applying the integrative framework to the case of Macon County, North Carolina, highlights the trade-offs and complexities involved in addressing issues of exurbanization in the Southern Appalachian region. This case study illustrates the need for nuance in defining problems surrounding already polarized issues. Trade-offs will be necessary in any negotiation related to conservation. Therefore, it can be very effective if conflict surrounding specific values, e.g., cultural, economic, or ecological, is acknowledged upfront. In analyzing multiple perspectives through the integrative framework's three lenses of values and valuation, process and governance, and power and inequality, we arrived not at a more focused definition of a problem, but at one that grants complexity and conflict the same merit as simplification and resolution.

Conservation and development issues in Macon County are continually being defined and redefined in an iterative process that suggests not one problem and one solution, but an evolving and emergent set of processes that will include many voices and many decisions over a long period of time. What the integrative framework calls for, and what we have attempted to demonstrate the need for, is transparent negotiation based on deliberate and democratic thought. Although this may complicate the efforts of decision makers, it does acknowledge the difficult choices that will have to be made and the explicit need to focus on trade-offs.

There is more work to be done in refining and applying the integrative framework to conservation issues. This includes a discussion of what it means to apply a conceptual framework to a materially felt process like exurbanization. In calling this framework 'integrative,' the relationship between science and policy must be explored and questions such as "How does 'better problem definition' benefit Macon County?" need to be addressed. By illuminating the intricacies of the social-ecological system, we hope to guide inclusive decisions that work through multiple understandings of conservation issues with the hopes of effecting fewer unintended consequences.

Responses to this article can be read online at: http://www.ecologyandsociety.org/issues/responses. $\mathrm{php} / 5970$ 


\section{Acknowledgments:}

This project was supported by a grant from the National Science Foundation to the Coweeta Long Term Ecological Research (LTER) program (DEB-0823293).

\section{LITERATURE CITED}

Advancing Conservation in a Social Context (ACSC). 2011. Advancing conservation in a social context: working in a world of trade-offs. Final Report. Center for Integrative Conservation Research, Athens, Georgia, USA. [online] URL: http://cicr.ovpr. uga.edu/files/2012/03/ACSC final report.pdf

Anderson, Z. R., P. D. Hirsch, and T. O. McShane. 2012. An analysis of conservation and development trade-offs at the Cat Tien National Park, Vietnam. Pages 309-331 in T. C. H. Sunderland, J. Sayer, and H. Minh-Ha, editors. Evidence-based conservation: lessons from the Lower Mekong. Routledge, New York, New York, USA. [online] URL: http://www.cifor.org/ publications/pdf files/Books/BSunderland1301.pdf

Audrey, A., M. Briggs, and K. Kroesen. 2009. Preparing for human expansion into exurban riparian areas. Pages 181-198 in A. X. Esparza and G. McPherson, editors. The planner's guide to natural resource conservation: the science of land development beyond the metropolitan fringe. Springer, New York, New York, USA.

Berube, A., A. Singer, J. H. Wilson, and W. H. Frey. 2006. Finding exurbia: America's fast-growing communities at the metropolitan fringe. Brookings Institution, Washington, D.C., USA. [online] URL: http://www.brookings.edu/ /media/research/files/reports/2006/10/ metropolitanpolicy $\% 20$ berube/20061017 exurbia.pdf

Boucquey, N., L. M. Campbell, G. Cumming, Z. A. Meletis, C. Norwood, and J. Stoll. 2012. Interpreting amenities, envisioning the future: common ground and conflict in North Carolina's rural coastal communities. Geojournal 77(1):83-101. http://dx.doi. org/10.1007/s10708-010-9387-1

Bradley, C. A., and S. Altizer. 2007. Urbanization and the ecology of wildlife diseases. Trends in Ecology and Evolution 22(2):95-102. http://dx.doi.org/10.1016/j.tree.2006.11.001

Brandon, K. E. and M. Wells. 1992. Planning for people and parks: design dilemmas. World Development 20:557-570. http:// dx.doi.org/10.1016/0305-750X(92)90044-V

Brett, J. R. 1956. Some principles in the thermal requirements of fishes. Quarterly Review of Biology 31(2):75-87.

Canfield, E., and R. H. Hawkins. 2009. Storm water management in exurbia. Pages 199-213 in A. X. Esparza and G. McPherson, editors. The planner's guide to natural resource conservation: the science of land development beyond the metropolitan fringe. Springer, New York, New York, USA. http://dx.doi. org/10.1007/978-0-387-98167-3 11

Casado-Diaz, M. A. 1999. Socio-demographic impacts of residential tourism: a case study of Torrevieja, Spain. International Journal of Tourism Research 1(4):223-237. http://dx. doi.org/10.1002/(SICI)1522-1970(199907/08)1:4<223::AID-JTR153>3.0. $\mathrm{CO} ; 2-\mathrm{A}$
Cash, D. W., W. N. Adger, F. Berkes, P. Garden, L. Lebel, P. Olsson, L. Pritchard, and O. Young. 2006. Scale and cross-scale dynamics: governance and information in a multilevel world. Ecology and Society 11(2): 8. [online] URL: http://www.ecologyandsociety. org/voll1/iss $2 / \operatorname{art} 8 /$

Cho, S.-H., D. H. Newman, and D. N. Wear. 2005. Community choices and housing demands: a spatial analysis of the Southern Appalachian Highlands. Housing Studies 20(4):549-569. http:// dx.doi.org/10.1080/02673030500114433

Clinton, B. D., and J. M. Vose. 2006. Variation in stream water quality in an urban headwater stream in the Southern Appalachians. Water, Air, and Soil Pollution 169:331-353. http:// dx.doi.org/10.1007/s11270-006-2812-X

Costanza, R., R. d'Arge, R. de Groot, S. Farber, M. Grasso, B. Hannon, K. Limburg, S. Naeem, R. V. O’Neill, J. Paruelo, R. G. Raskin, P. Sutton, and M. van den Belt. 1997. The value of the world's ecosystem services and natural capital. Nature 387 (6630):253-260. http://dx.doi.org/10.1038/387253a0

Costello, L. 2007. Going bush: the implications of urban-rural migration. Geographical Research 45(1):85-94. http://dx.doi. org/10.1111/j.1745-5871.2007.00430.x

Cross, W. F., J. B. Wallace, and A. D. Rosemond. 2007. Nutrient enrichment reduces constraints on material flows in a detritusbased food web. Ecology 88(10):2563-2575. http://dx.doi. org/10.1890/06-1348.1

Culbertson, K., D. Case, D. Fowler, H. Morgan, and S. Schwellenbach. 2008. Moving to the mountains: amenity migration in the Sierra and Southern Appalachian Mountains. Page 217 in J. L. Wescoat, Jr. and D. M. Johnston, editors. Political economies of landscape change: places of integrative power. Springer, New York, New York, USA.

Daily, G. C. 1997. Nature's services: societal dependence on natural ecosystems. Island, Washington, D.C., USA.

Dent, Jr., H. S. 1998. The roaring 2000's: building the wealth and life style you desire in the greatest boom in history. Simon and Schuster, New York, New York, USA.

Egan, A. F., and A. E. Luloff. 2000. The exurbanization of America's forests: research in rural social science. Journal of Forestry 98(3):26-30.

Esparza, A. X. 2009. Exurbanization and Aldo Leopold's humanland community. Pages 3-26 in A. X. Esparza and G. McPherson, editors. The planner's guide to natural resource conservation. Springer, New York, New York, USA. http://dx.doi. org/10.1007/978-0-387-98167-3 1

Esparza, A. X., and J. I. Carruthers. 2000. Land use planning and exurbanization in the rural mountain west: evidence from Arizona. Journal of Planning Education and Research 20:23-36. http://dx.doi.org/10.1177/073945600128992573

Glennon, M., and H. Kretser. 2005. Impacts to wildlife from low density, exurban development: information and considerations for the Adirondack Park. Technical Paper No. 3. Wildlife Conservation Society, Adirondack Communities and Conservation Program, Saranac Lake, New York, USA. 
Gosnell, H., and J. Abrams. 2011. Amenity migration: diverse conceptualizations of drivers, socioeconomic dimensions, and emerging challenges. Geojournal (76):303-322. http://dx.doi. org/10.1007/s10708-009-9295-4

Gragson, T. L., and P. V. Bolstad. 2006. Land use legacies and the future of Southern Appalachia. Society and Natural Resources: An International Journal 19(2):175-190. http://dx.doi. org/10.1080/08941920500394857

Hansen, A. J., R. L. Knight, J. M. Marzluff, S. Powell, K. Brown, P. H. Gude, and K. Jones. 2005. Effects of exurban development on biodiversity: patterns, mechanisms, and research needs. Ecological Applications 15(6):1893-1905. http://dx.doi.org/10.1890/05-5221

Harrison, S. 2005. Biodiversity and wilderness: the need for systematic protection of biological diversity. Journal of Land, Resources, and Environmental Law 25:53-62.

Hirsch, P. D., W. A. Adams, J. P. Brosius, A. Zia, N. Bariola, and J. L. Dammert. 2010. Acknowledging conservation trade-offs and embracing complexity. Conservation Biology 25(2):259-264. http://dx.doi.org/10.1111/j.1523-1739.2010.01608.x

Hirsch, P. D., J. P. Brosius, S. O’Conner, A. Zia, M. Welch-Devine, J. L. Dammert, A. Songorwa, T. C. Trung, J. L. Rice, Z. R. Anderson, S. Hitchner, J. Schelhas, and T. O. McShane. 2013. Navigating complex trade-offs in conservation and development: an integrative framework. Issues in Interdisciplinary Studies 31:99-122.

Kaushal, S. S., W. M. Lewis, and J.H. McCutchan, Jr. 2006. Land use change and nitrogen enrichment of a Rocky Mountain Watershed. Ecological Applications 16:299-312. http://dx.doi. org/10.1890/05-0134

Kirk. R. W., P. V. Bolstad, and S. M. Manson. 2012. Spatiotemporal trend analysis of long-term development patterns (1900-2030) in a Southern Appalachian county. Landscape and Urban Planning 104:47-58. http://dx.doi.org/10.1016/j. landurbplan.2011.09.008

Kuhman, T. R., S. M. Pearson, and M. G. Turner. 2010. Effects of land-use history and the contemporary landscape on nonnative plant invasion at local and regional scales in the forestdominated southern Appalachians. Landscape Ecology 25:1433-1445. http://dx.doi.org/10.1007/s10980-010-9500-3

Lehtinen, R. M., S. M. Galatowitsch, and J. R. Tester. 1999. Consequences of habitat loss and fragmentation for wetland amphibian assemblages. Wetlands 19(1):1-12. http://dx.doi. org/10.1007/BF03161728

Little Tennessee Watershed Association (LTWA). 2007. The state of the streams in the Upper Little Tennessee Watershed: a report on water quality and habitat trends, 1990-2002. Little Tennessee Watershed Association, Franklin, North Carolina, USA.

Liu, J., T. Dietz, S. R. Carpenter, M. Alberti, C. Folke, E. F. Moran, A. N. Pell, P. Deadman, T. Kratz, J. Lubchenco, E. Ostrom, Z. Ouyang, W. Provencher, C. L. Redman, S. H. Schneider, and W. W. Taylor. 2007. Complexity of coupled human and natural systems. Science 317:1513-1516. http://dx.doi. org/10.1126/science. 1144004

Lohse, K. A., and A. M. Merenlender. 2009. Impacts of exurban development on water quality. Pages 3-26 in A. X. Esparza and
G. McPherson, editors. The planner's guide to natural resource conservation. Springer, New York, New York, USA. http://dx.doi. org/10.1007/978-0-387-98167-3 9

Maestas, J. D., R. L. Knight, and W. C. Gilgert. 2001. Biodiversity and land-use change in the American mountain west. Geographical Review 91:509-524. http://dx.doi.org/10.2307/3594738

McCarthy, J. 2008. Rural geography: globalizing the countryside. Progress in Human Geography (32)1:129-137. http://dx.doi. org/10.1177/0309132507082559

McGranahan, D. A. 1999. Natural amenities drive rural population change. Agricultural Economic Report No. (AER-781). U.S. Department of Agriculture, Economic Research Service, Washington, D.C., USA. [online] URL: http://www.ers.usda.gov/ publications/aer-agricultural-economic-report/aer781.aspx\#.Uaz$\underline{\text { edJO-30 }}$

McShane, T. O., P. D. Hirsch, T. C. Trung, A. N. Songorwa, A. Kinzig, B. Monteferri, D. Mutekanga, H. V. Thang, J. L. Dammert, M. Pulgar-Vidal, M. Welch-Devine, J. P. Brosius, P. Coppolillo, and S. O'Connor. 2011. Hard choices: making tradeoffs between biodiversity conservation and human well-being. Biological Conservation 144:966-972. http://dx.doi.org/10.1016/j. biocon.2010.04.038

McShane, T. O., and M. P. Wells. 2004. Getting biodiversity projects to work: towards more effective conservation and development. Columbia University Press, New York, New York, USA.

Nelson, A. C., W. J. Drummond, and D. S. Sawicki. 1995. Exurban industrialization: implications for economic development policy. Economic Development Quarterly 9:119-133. http://dx.doi. org/10.1177/089124249500900202

Nelson, A. C., and K. J. Dueker. 1990. The exurbanization of America and its planning policy implications. Journal of Planning Education and Research 9:91-100. http://dx.doi.org/10.1177/0739456X9000900201

North Carolina Ecosystem Enhancement Program (NCEEP). 2010. Franklin to Fontana local watershed plan: Little Tennessee River Basin, Swain and Macon Counties, North Carolina. Phase II: watershed assessment report. North Carolina Ecosystem Enhancement Program and Equinox Environmental Consulting and Design, Asheville, North Carolina, USA. [online] URL: http://www.nceep.net/services/lwps/Little Tennessee/New/ F2F WAR ExecSummTOC Oct2010.pdf

North Carolina Ecosystem Enhancement Program (NCEEP). 2011. Franklin to Fontana local watershed plan phase III. Upper Little Tennessee River Basin, Swain and Macon Counties, North Carolina. Project atlas. North Carolina Ecosystem Enhancement Program and Equinox Environmental Consulting and Design, Asheville, North Carolina, USA. [online] URL: http://www. nceep.net/services/lwps/Little Tennessee/New/F2F\%20P3\%20Atlas FinalReduced LOnamesremoved AJL 12oct2011.pdf

Phillips, A. 2003. Turning ideas on their head: a new paradigm for protected areas. George Wright Forum 20(2):8-32.

Price, K., and D. S. Leigh. 2006. Comparative water quality of lightly- and moderately-impacted streams in the Southern BlueRidge Mountains, USA. Environmental Monitoring and Assessment 120:269-300. http://dx.doi.org/10.1007/s10661-005-9060-1 
Radeloff, V. C., S. I. Stewart, T. J. Hawbaker, U. Gimmi, A. M. Pidgeon, C. H. Flather, R. B. Hammer, and D. P. Helmers. 2010. Housing growth in and near United States' protected areas limits their conservation value. Proceedings of the National Academy of Sciences 107(2):940-945. http://dx.doi.org/10.1073/pnas.0911131107

Ráez-Luna, E., and J. L. Dammert Bello. 2012. Reflexiones y lecciones sobre la toma de decisiones ante grandes proyectos minero-energéticos en el Perú: el caso de la hidroeléctrica inambari en la Amazonía Peruana. Cuaderno de investigación (Vol. 7). Peruvian Society of Environmental Law (SPDA), Lima, Peru.

Rasker, R. 2006. An exploration into the economic impact of industrial development versus conservation on western public lands. Society and Natural Resources: An International Journal 19 (3):191-207. http://dx.doi.org/10.1080/08941920500460583

National Association of Realtors. 2002. The 2002 National Association of Realtors profile of second-home owners. National Association of Realtors, Washington, D.C., USA.

Reynolds-Hogland, M. J., and M. S. Mitchell. 2007. Effects of roads on habitat quality for bears in the Southern Appalachians: a long-term study. Journal of Mammalogy 88(4):1050-1061. http:// dx.doi.org/10.1644/06-MAMM-A-072R1.1

Robbins, P., S. Martin, and S. Gilbertz. 2012. Developing the commons: the contradictions of growth in exurban Montana. Professional Geographer 64(3):317-331. http://dx.doi. org/10.1080/00330124.2011.601193

Southern Appalachian Man and the Biosphere (SAMAB). 1996. The Southern Appalachian assessment social/culturalleconomic technical report. Southern Appalachian Man and the Biosphere (SAMAB) and U.S. Department of Agriculture, Southern Region, Atlanta, Georgia, USA. [online] URL: http://www. $\underline{\text { samab.org/site/wp-content/uploads/2011/06/SAA-social.pdf }}$

Spectorsky, A. C. 1955. The exurbanites. 1st ed. Lippincott, Philadelphia, Pennsylvania, USA.

Storm, D. J., C. K. Nielson, E. M. Shauber, and A. Woolf. 2007. Deer-human conflict and hunter access in an exurban landscape. Human-Wildlife Conflicts 1(1):53-59.
Swift, Jr., L. W., and J. B. Messer. 1971. Forest cuttings raise temperatures of small streams in the southern Appalachians. Journal of Soil and Water Conservation 26(3):111-116.

Turner, M. G., S. M. Pearson, P. Bolstad, and D. N. Wear. 2003. Effects of land-cover change on spatial pattern of forest communities in the Southern Appalachian Mountains (USA). Landscape Ecology 18:449-464. http://dx.doi.org/10.1023/ A:1026033116193

Walters, D. M., A. H. Roy, and D. S. Leigh. 2009. Environmental indicators of macroinvertebrate and fish assemblage integrity in urbanizing watersheds. Ecological Indicators 9:1222-1233. http:// dx.doi.org/10.1016/j.ecolind.2009.02.011

Webster, J. R., E. F. Benfield, K. K. Cecala, J. F. Chamblee, C. A. Dehring, T. Gragson, J. H. Cymerman, C. R. Jackson, J. D. Knoepp, D. S. Leigh, J. C. Maerz, C. Pringle, and H. M. Valett. 2012. Water quality and exurbanization in Southern Appalachian streams. Pages 90-106 in P. J. Boon and P. J. Raven, editors. River conservation and management. John Wiley and Sons, London, UK. http://dx.doi.org/10.1002/9781119961819.ch8

Wenger, S. J., D. J. Isaak, C. H. Luce, H. M. Neville, K. D. Fausch, J. B. Dunham, D. C. Dauwalter, M. K. Young, M. M. Elsner, B. E. Rieman, A. F. Hamlet, and J. E. Williams. 2011. Flow regime, temperature, and biotic interactions drive differential declines of trout species under climate change. Proceedings of the National Academy of Sciences 108(34):14175-14180. http://dx.doi. org/10.1073/pnas. 1103097108

Western, D., and R. Wright. 1994. The background to community-based conservation. Pages 1-12 in D. Western and R. Wright, editors. Natural connections: perspectives in communitybased conservation. Island, Washington, D.C., USA.

Wittemyer, G., P. Elsen, W. T. Bean, A. C. Burton, and J. S. Brashares. 2008. Accelerated human population growth at protected area edges. Science 321(5885):123-126. http://dx.doi. org/10.1126/science. 1158900

Zia, A., P. Hirsch, A. Songorwa, D. R. Mutekanga, S. O'Connor, T. McShane, P. Brosius, and B. Norton. 2011. Cross-scale value trade-offs in managing social-ecological systems: the politics of scale in Ruaha National Park, Tanzania. Ecology and Society 16 (4): 7. http://dx.doi.org/10.5751/ES-04375-160407 